\title{
BEETLE DIVERSITY ASSOCIATED WITH FOREST STRUCTURE INCLUDING DEADWOOD IN SOFTWOOD AND HARDWOOD STANDS IN NOVA SCOTIA
}

\author{
DANIEL KEHLER, SØREN BONDRUP-NIELSEN* and CRISTINE CORKUM \\ Centre for Wildlife and Conservation Biology \\ Acadia University \\ Wolfville, Nova Scotia, Canada, BOP $1 \times O$
}

\begin{abstract}
Associations between beetles and forest stand characteristics, as well as beetle diversity, were investigated for 41 forest stands in Nova Scotia, Canada. Over 200 morphospecies from 45 Families of beetles were caught using window flight-intercept traps. In both years, correspondence analysis revealed distinct groupings of softwood and hardwood stands based on species assemblages. Multiple regression analysis was used to determine associations between forest variables and total species richness. Analyses were conducted for all stands combined and for hardwood and softwood stands separately. Hardwood stands had greater beetle richness than softwood stands. Within hardwood stands, volume of intermediate-sized deadwood was the best predictor of total species richness. Within softwood stands, volume of well-decayed deadwood was the best predictor of total beetle richness. Deadwood volume was associated with stand age in softwoods, and it appears that over 140 years is required for deadwood volume to reach pre-disturbance levels.
\end{abstract}

\begin{abstract}
On a étudié des associations entre les coléoptères et les caractéristiques des peuplements ainsi que la diversité des coléoptères pour 41 peuplements de la Nouvelle-Écosse, au Canada. Plus de 200 morphoespèces appartenant à 45 familles de coléoptères ont été capturées à l'aide de pièges-fenêtres. Pour les deux années, des analyses de correspondance ont révélé des regroupements distincts dans les peuplements de résineux et de feuillus, d'après les assemblages d'espèces. On s'est servi d'une analyse de régression multiple pour établir des associations entre des variables des forêts et la richesse totale en espèces. Des analyses ont été effectuées pour l'ensemble des1 peuplements et séparément pour les peuplements de feuillus et pour les peuplements de résineux. La richesse en coléoptères était plus grande dans les peuplements de feuillus, pour lesquels le volume de bois mort de taille moyenne constituait le meilleur indicateur de la richesse totale en espèces. En ce qui concerne les peuplements de résineux, c'était le volume de bois mort bien décomposé qui était le meilleur indicateur de la richesse totale en coléoptères. Dans le cas des résineux, le volume de bois mort était associé à l'âge du peuplement, et il semble qu'il faille plus de 140 ans pour retrouver les niveaux pré-perturbation.
\end{abstract}

\section{Introduction}

In conservation, it is important that we understand the processes and patterns in an ecosystem responsible for the generation, maintenance, and loss of biodiversity. The study of habitat associations allows one to identify key patterns correlated with species diversity by relating ecological parameters to the distribution and abundance of species. Most studies of habitat associations for vertebrates involve single species, and many give only qualitative information about habitat associations (e.g. Bias \& Gutierrez 1992, Adams \& Morrison 1993, Conway \& Martin 1993, but see Lindenmayer et al. 1993, Pausas et al. 1995). In forest management, qualitative information on species assemblages may prove most useful in designing forestry practices that maintain biodiversity.

The importance of dead and decaying wood has been the subject of recent interest in forest management (Maser 1994). A number of authors have examined the relationship between forestry and coarse woody debris dynamics (e.g. Gore \& Patterson 1986, Kirby et al. 1991, Hagan \& Grove 1996), especially as it relates to older forests (Harmon \& Hua 1991, Stewart \& Burrows 1994, Tyrell \& Crow 1994).

\footnotetext{
* Author to whom correspondence should be addressed.
} 
Deadwood is involved in a number of ecological processes in forests. The presence of deadwood reduces soil erosion, affects soil development, acts as a seedbed for forest plants, and plays a role in energy and nutrient flow by storing water and nutrients (Franklin et al. 1981, Harmon et al. 1986). Deadwood probably also sequester carbon, but this area has received little work to date (Harmon et al. 1990, Harmon \& Hua 1991). In forested ecosystems, deadwood also provides habitat for a multitude of organisms, including fungi (Bader et al. 1995), bryophytes (Söderström \& Jonson 1992), birds (Angelstam \& Mikusinski 1994) and insects (Brown 1991, Siitonen 1994).

Insects have long been of interest to foresters, primarily as competitors for valuable wood resources. Due to the recent attention to biodiversity, interest in non-pest insect species living in forests has increased. Research in Scandinavia, where there is a long history of intensive forest management, has revealed the decline of hundreds of forest species as a result of forestry operations (Stokland 1991). These species are not traditional indicator or flagship species, such as birds or mammals, but rather invertebrates, fungi and spore-bearing plants. Several hundred forest invertebrates have been red-listed in Sweden, including over 500 species of beetles (Berg et al. 1994). In Sweden, old trees, logs and snags have been identified as important habitat elements for endangered invertebrates, fungi, lichens and bryophytes (Berg et al. 1994). In addition, a number of habitat associations have been documented between saproxylic insects and deadwood parameters, such as different tree species, moisture content, temperature, and nutrient status of dead and decaying wood (Ikeda 1987, Warren \& Key 1991, Araya 1993).

Beetles (Order Coleoptera) are the most numerically rich taxa with over 300,000 species described (Papp 1984). Beetles serve a variety of roles in forests: as prey for other organisms, such as insectivorous birds, as predators, as pollinators, as herbivores, and as decomposers (Dillon \& Dillon 1972). Relative to some invertebrate groups, beetle taxonomy is fairly well known, and previous research from Scandinavia and elsewhere has documented significant associations between beetles and different deadwood characteristics, as well as negative impacts such as species loss resulting from forestry operations (Niemelä et al. 1988, 1993, Chandler \& Peck 1992, Baguette \& Gerard 1993, Buse \& Good 1993, Halme \& Niemelä 1993, Greenberg \& Thomas 1995, Michaels \& McQuillan 1995).

Very little is known about the status of beetles and beetle habitat associations in the North American Northern Hardwood Forest. This knowledge is essential in designing forest management practices that are sensitive to beetle habitat requirements. This present study documents habitat associations of beetles in the Acadian forest, a subsection of the Northern Hardwood Forest (Loucks 1959). More specifically, we were interested in 1) performing a partial inventory of forest beetles, 2) determining aspects of forest structure correlated with beetle species richness, and 3) quantifying deadwood volumes in different forest types.

\section{Methods}

Sampling took place in central Nova Scotia within an area $300 \mathrm{~km}$ long by up to $100 \mathrm{~km}$ wide (Fig 1). Beetles were sampled at the level of the forest stand. Stands to be sampled were selected randomly from stands that met the following criteria: Softwood stands were greater than $70 \%$ red spruce (Picea rubens) and balsam fir (Abies balsamea); Hardwood stands were greater than 70\% sugar maple (Acer saccharum), red maple (Acer rubrum), yellow birch (Betula alleghaniensis) and white birch (Betula papyrifera). Stands had to be greater than $2.5 \mathrm{ha}$, and were greater than $300 \mathrm{~m}$ from 


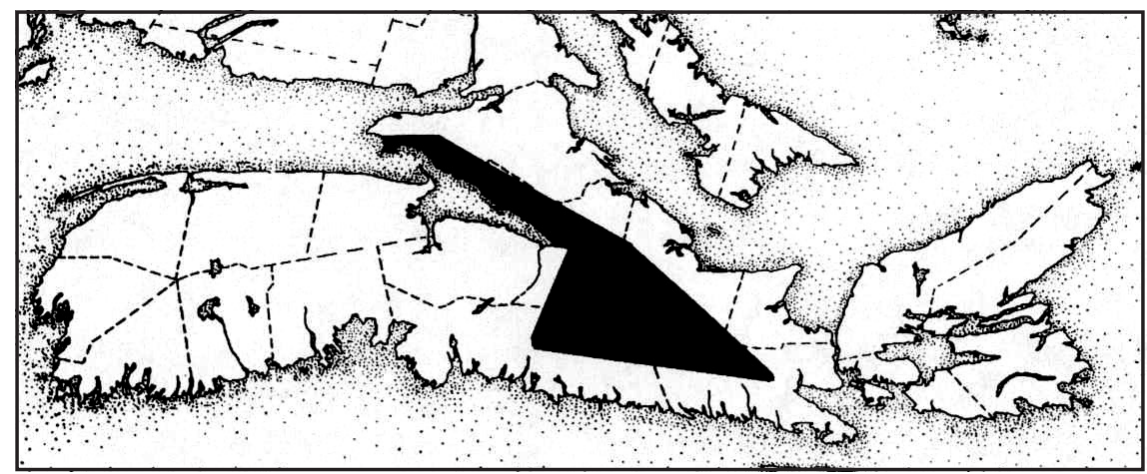

Fig 1 Map of Nova Scotia. Blackened area represents general location of sampling sites.

any road. In 1994, 11 hardwood and 10 softwood stands were sampled, and in 1995, 10 softwood and 10 hardwood stands were sampled, for a total of 41 forest stands. The window flight-intercept trap was used to sample for beetles. This trap type has been used successfully (Bakke 1975, Økland et al. 1996, Stokland 1997, Siitonen 1994, Sippola et al. 1992). This passive sampling technique is suited for catching flying Coleoptera (Marshall et al. 1994), many of which in forests are deadwood-requiring Coleoptera (Økland 1996, Stokland 1994). Of 513 beetle species caught in flight intercept traps by Økland (1996), 194 (37.8\%) were known obligate deadwood associates, representing $27.7 \%$ of all deadwood associates in Norway.

Flight-intercept traps were constructed from two $30 \times 30 \mathrm{~cm}$ pieces of transparent plastic, connected at a right angle to form two bisecting planes, with opaque plastic rain covers above and funnels below. A $50 \%$ water/ $50 \%$ ethylene glycol mixture was used in the collection vial under the funnel to preserve beetles that had fallen into the trap. In 1994, beetles were sampled from July 10 to August 31, using 3 traps per stand. In 1995, beetles were sampled from May 1 to July 31, using 6 traps per stand. All traps were hung at a minimum distance of $50 \mathrm{~m}$ from the stand edge and then every $35 \mathrm{~m}$ on a transect running through the middle of the stand. Traps were hung at a height of $1.5 \mathrm{~m}$ from existing tree branches. Traps were emptied every nine days in 1994 and every 14 days in 1995. The difference in methodology between years could affect the results but to control for this a 'year effect' was incorporated in the analyses.

The contents of each sample from the traps were rinsed and transferred to $70 \%$ ethanol. The contents were then sorted, separating the beetles from the rest of the material. The beetles from each sample were then sorted into morphospecies under a dissection microscope. One individual of each sorted group from each collection was pinned for later identification. This collection is housed at the Nova Scotia Museum of Natural History, Halifax, Nova Scotia, where identification of pinned specimens is being carried out by an insect taxonomist.

In 1994, 3 vegetation sampling points were used per stand, located at each trap. A prism sweep (BAF 1) was used to determine percent hardwood basal area (PERCHWBA), hardwood and softwood basal area (HWBA and SWBA), as well as hardwood, softwood and total tree density (HWDENS, SWDENS and TOTDENS) (Avery 1967). Two trees of mean diameter (based on trees in prism sweep) were cored at breast height using an increment bore to determine age (AGE) and the amount of deadwood was 
quantified by volume using a $10 \mathrm{~m} \times 10 \mathrm{~m}$ quadrat centered on each trap (DWTOT). For each piece of deadwood $>5 \mathrm{~cm}$ at the smallest end, the length, diameter at both ends, and decompositional state was recorded. Decompositional state included three categories: STATE1 - hard: no penetration when probed by metal calipers, STATE2 intermediate: outer soft, inner hard. Partial penetration by steel calipers, STATE3 - soft: easily penetrable throughout using steel calipers. Deadwood was also divided into 3 size classes: SIZE1 - largest diameter between 5 and $15 \mathrm{~cm}$, SIZE2 - largest diameter between 15 and $30 \mathrm{~cm}$, SIZE3 - largest diameter $>30 \mathrm{~cm}$. Deadwood volume was calculated for each piece based on the frustrum of a cone (Harmon \& Sexton 1996)

In 1995, 6 prism sweeps were conducted at a random distance up to $50 \mathrm{~m}$ from each trap perpendicular to the axis of the trap line. To quantify deadwood, we used ten $10 \mathrm{~m} \times 10 \mathrm{~m}$ quadrats, spaced at 20 metre intervals along the trap line and at a random distance up to $50 \mathrm{~m}$ from each trap, perpendicular to the axis of the trap line. The location of each successive prism sweep and deadwood quadrat alternated from one side of the trap line to the other. In 1995, the largest tree in each prism sweep was cored. In both years, the ages of older hardwoods stands were not measurable using the increment bore due to blurriness of the rings and extensive heart rot. Thus no analyses using age were possible for hardwood stands.

The larger number of prism sweeps and deadwood plots were required in 1995 to adequately characterize the habitat surrounding the larger number of traps. However, only averages for all attributes per stand are used in analyses, thus greatly decreasing the chance that differences in methodology should have any consequence.

\section{Statistical Analysis}

To evaluate the flight-intercept method of trapping, we calculated a species accumulation curve for the 6 traps used in 1995. The species accumulation curve is based on the cumulative number of species added to the stand total as each additional trap is considered. To derive the curve, we randomized the trap order within stands 10 times and calculated the cumulative number of species with each additional trap for each randomization. These results were then averaged across the 20 stands.

A draw back of the flight-intercept method of catching beetles is that abundances among species cannot be compared as different species have different flight behaviours. Furthermore, only beetles with flight behaviour such that they intercept the trap are caught. For example, if traps are hung at one metre above the ground, beetles that fly above or below that height will not be caught. Thus, catching only one specimen of a particular species does not signify that it is rare. It is only rare with respect to the particular trapping method. Therefore, it is important to keep in mind that a beetle sample from a flight-intercept trap only represents a subsample of species of beetles. Thus only presence/absence of species should be analysed. Therefore, the variable 'total species richness' is used as the response variable in this study.

As beetles caught differed with respect to many ecological and physiological characteristics, it is unlikely that any single trap type will sample all species equally. Thus, we did not use information about abundance when comparing among species, but focused on presence/absence and species richness.

Correspondence analysis (ter Braak 1994), an ordination technique, was used to groups stands according to beetle species composition. Correspondence analysis is based on species showing a unimodal response of abundance to an environmental gradient (ter Braak 1994). This assumes that for every species and every environmental variable, there is an optimal range where that species is best adapted. Stand scores are 
calculated in such a way that stands that lie in close proximity on the ordination biplot are similar in species composition, and distant stands are dissimilar in species composition. Correspondence analysis was performed, based on species incidence data, for each year separately using CANOCO (ter Braak 1988).

Multiple linear regression analysis was used to relate total species richness to the forest structure variables. Analyses were conducted for all stands together and for hardwood and softwood stands separately. For each response variable, a forward stepwise procedure was used. The criterion for exit and entry of variables was set at $p=0.05$. Residuals were plotted against fitted values to check for heteroscedasticity, quantile-quantile plots were used to assess normality of the residuals, and Cook's distance plots were used to check for influential observations. To account for the differences in sampling intensity and period between years, the binary variable YEAR was first included in each model. Unfortunately, the variable YEAR will not only be a function of differences in methodology between years but also differences in weather and random variation between years. Partial $R^{2}$ values were calculated based on the variance remaining after including YEAR in the model. All linear and generalized linear models were performed using S-PLUS (Mathsoft 1995).

\section{Results}

A total of 17,358 individual beetles were caught, representing over 200 morpho-species, from 46 Families (Appendix 1). Some specimens were sent to Agriculture and AgriFood Biosystematic Research Centre, Ottawa, Canada for identification. Of these two were undescribed species.

The daily capture rate per trap was 1.23 (Table 1 ). The cumulative number of species caught showed a continuous increase up to 6 traps (Fig 2) and the majority of species were caught in only one trap. Thus, increasing the number of traps appears to increase the likelihood of catching species that are rare or less likely to be caught in this trap type. In both sampling years, correspondence analyses revealed a clustering of hardwood and softwood stands (Fig 3) indicating a consistent difference between the beetle species composition of hardwood and softwood stands. The separation between stand types seemed to be more evident in 1995 where softwoods also showed more variation in species composition than hardwoods.

Table 1 Overview of trapping results. Results are given for each year separately and for both years together.

\begin{tabular}{lccc}
\hline & $\mathbf{1 9 9 4}$ & $\mathbf{1 9 9 5}$ & Total \\
\hline Beetles Caught & 3591 & 13767 & 17358 \\
Trap Days & 4284 & 9840 & 14134 \\
Beetles/Trap Day & 0.838 & 1.40 & 1.23 \\
Identified Families & 34 & 42 & 46 \\
\hline
\end{tabular}

The results of multiple regression analyses revealed the importance of percent hardwood basal area in explaining total beetle species richness (Table 2). Moreover, for total species richness only one explanatory variable (SIZE2) entered the model. Hardwood stands proved to have a higher species richness than softwood stands. However, when hardwood and softwood stands are considered separately beetle 


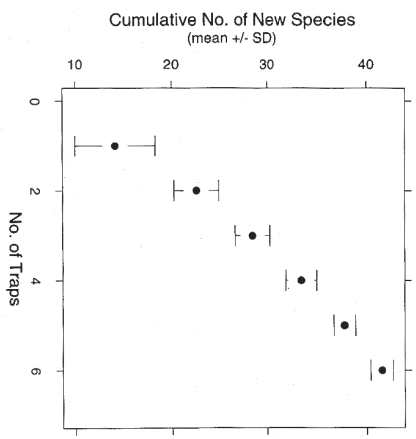

Fig 2 Species accumulation curve for 1995, based on 10 randomizations of trap order in each stand, and averaged across all 20 stands.

1994

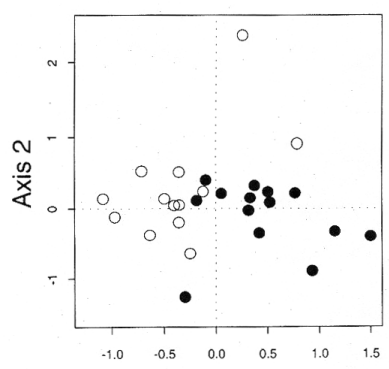

1995

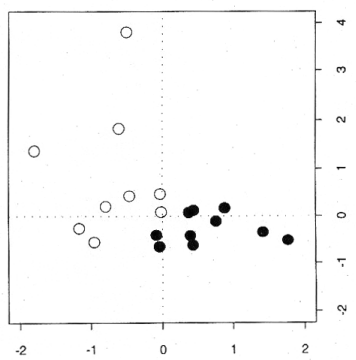

Axis 1

Fig 3 Results of correspondence analysis. Stands locations are plotted on species-space based on their values from the first two axes of the correspondence analysis. Open circles represent hardwood stands and filled circles represent softwood stands. Results from 1994 and 1995 are presented separately.
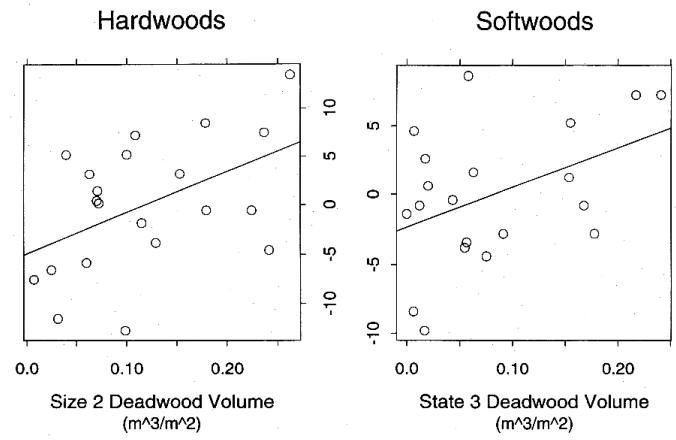

Fig 4 Relationship between SIZE2 deadwood volume and total richness in hardwood stands, and STATE3 deadwood volume and total richness in softwood stands. To control for the effect of YEAR, deadwood volumes are plotted against the residuals of a model where total richness is regressed against YEAR. 
species richness is best predicted by deadwood variables (Table 3). For hardwood stands, intermediate-sized deadwood (SIZE2) proved to be the best predictor for total species richness (Fig 4). For softwood stands, well-decayed deadwood (STATE3) proved to be the best predictor of total species richness (Figure 4).

Table 2 Results of multiple regression on total species richness and species richness of each associate group for all stands. Independent variables for each model are presented by order of entry. $R^{2}$ values are given for each independent variable and for independent variables once the effect of year is removed $\left(R^{2 *}\right)$. Significance ( $p$-value) was assessed using $\mathrm{F}$ tests. All relationships are positive.

\begin{tabular}{lllll}
\hline Response & Predictor & p-value & $\mathbf{R}^{\mathbf{2}}$ & $\mathbf{R}^{2 *}$ \\
\hline Total Richness & Year & 0.0000 & 0.74 & \\
& Perchwba & 0.0000 & 0.12 & 0.46 \\
& Size2 & 0.0110 & 0.02 & 0.09 \\
\hline
\end{tabular}

Table 3 Results of multiple regression on total species richness and species richness of each associate group for hardwood and softwood stands separately. Independent variables for each model are presented by order of entry. $R^{2}$ values are given for each independent variable and for independent variables once the effect of year is removed $\left(\mathrm{R}^{2 *}\right)$. Significance ( $\mathrm{p}$-value) was assessed using $\mathrm{F}$ tests. All relationships are positive except where noted by (-ve).

\begin{tabular}{llllllllll}
\hline & \multicolumn{3}{c}{ HARDWOOD STANDS } & \multicolumn{4}{c}{ SOFTWOOD STANDS } \\
& Predictor & $\mathbf{p}$-value & $\mathbf{R}^{\mathbf{2}}$ & $\mathbf{R}^{\mathbf{2 *}}$ & & Predictor & p-value & $\mathbf{R}^{\mathbf{2}}$ & $\mathbf{R}^{\mathbf{2 *}}$ \\
\hline Total Richness & Year & 0.000 & 0.85 & & Year & 0.000 & 0.84 & \\
& Size2 & 0.013 & 0.03 & 0.25 & State3 & 0.012 & 0.05 & 0.32 \\
& State2 & 0.023 & 0.02 & $0.20(-\mathrm{ve})$ & & & & \\
\hline
\end{tabular}

In softwood stands, where estimates of stand age were available, we examined relationships between all deadwood variables and stand age, while controlling for YEAR (Table 4). Only total volume, large-sized (SIZE3), and well-decayed (STATE3) deadwood volumes increased linearly with stand age. Figure 4 displays the relationship with STATE3 deadwood volume, which was also the best predictor of total species richness in softwood stands. Table 5 reports the mean deadwood volume for each deadwood size class and decompositional state, in softwoods and hardwoods. Volumes were similar between stand types, with the exception of SIZE1 deadwood volume, which was greater in softwood stands (Table 5).

Table 4 Results of simple linear regressions between stand age and deadwood variables in softwood stands, controlling forYEAR. $\mathrm{R}^{2 *}$ values are for the coefficient of determination after the effect of YEAR has been removed. Significance ( $p$-value) was assessed using $\mathrm{F}$ tests and significant results are bolded.

\begin{tabular}{lll}
\hline Variable & $\mathbf{R}^{2 *}$ & $\mathbf{p}$-value \\
\hline Size1 & 0.06 & 0.057 \\
Size2 & 0.33 & 0.29 \\
Size3 & 0.15 & $\mathbf{0 . 0 1 0}$ \\
State1 & 0.15 & 0.10 \\
State2 & 0.15 & 0.10 \\
State3 & 0.31 & $\mathbf{0 . 0 1 4}$ \\
Dwtot & 0.27 & $\mathbf{0 . 0 2 0}$ \\
\hline
\end{tabular}


Table 5 A comparison of deadwood volumes in different decompositional states and size classes between hardwood and softwood stands. Results presented are from a t-test (two-tailed, $\mathrm{n}=20$ ).

\begin{tabular}{|c|c|c|c|c|}
\hline & Softwoods & & $T$ & P-value \\
\hline Size1 & $0.10 \pm 0.050$ & $0.074 \pm 0.037$ & 2.21 & 0.032 \\
\hline Size2 & $0.15 \pm 0.13$ & $0.12 \pm 0.077$ & 0.96 & 0.35 \\
\hline Size 3 & $0.054 \pm 0.10$ & $0.071 \pm 0.074$ & 0.64 & 0.52 \\
\hline State1 & $0.13 \pm 0.10$ & $0.09 \pm 0.048$ & 1.68 & 0.1 \\
\hline State2 & $0.094 \pm 0.087$ & $0.11 \pm 0.077$ & 0.57 & 0.57 \\
\hline State3 & $0.082 \pm 0.076$ & $0.065 \pm 0.042$ & 0.89 & 0.37 \\
\hline Dwtot & $0.31 \pm 0.22$ & $0.26 \pm 0.1$ & 0.94 & 0.35 \\
\hline
\end{tabular}

\section{Discussion}

In this study, the use of the flight-intercept trap proved useful in the rapid generation of a biologically meaningful data set. However, it is important to keep in mind that, because of the limitations of the sampling methodology, the beetles species caught only represent a subsample of the total number of beetle species found in our study area. However, we found a higher beetle species richness in hardwood stands than in softwood stands. The method also allowed us to detect distinct differences in the beetle community composition of hardwoods and softwoods in both years of the study. Within softwood and hardwood stands, stands with high volumes of larger, well-decayed deadwood had higher species richness. Several deadwood variables were positively related to age in the softwood stands tested, and stands with high deadwood volumes were particularly favourable for many of the common species analyzed.

The daily capture rates per trap ( 1.23 beetles/ trap) were similar to those found in Finland of 1.16 (Sippola et al. 1995), but higher than those reported from Norway of 0.25 (Økland 1996) and 0.5 (Økland et al. 1996).

The species accumulation curve would suggest caution in the use of the flight-intercept trap. The trap tends to catch very few individuals of any one species, and in excess of 6 traps per stand is required in order to sample the majority of species susceptible to capture. In fact, observations (Bondrup-Nielsen 1996), suggest that the species accumulation curve does not asymptote even when using 40 traps per stand. These problems, however, may not be unique to the flight-intercept trap. Oliver and Beattie (1996a) report a very similar curve using 5 groups of 2 pitfall traps for beetles. The problem is less acute for ants and spiders, and may be a consequence of the higher diversity of beetles relative to other taxa. However, the results of the correspondence analysis also suggest that despite potential problems with the trap, trap catches were sensitive enough to allow hardwood stands and softwood stands to separate out on the basis of the beetle community, even with the use of only 3 traps per stand. 
It is important to consider that although a large number of species were sampled in this study, these species likely represent only a fraction of the actual beetle species richness in Nova Scotian forests. A variety of different trap types would be required to more effectively sample the forest beetle community (Marshall et al. 1994). The partial inventory of this study although based on morphospecies with voucher specimens kept in the Department of Biology Museum, Acadia University, represents benchmark data on the presence, distribution, and natural history of beetles in Nova Scotia, and as such, vital information for future monitoring efforts (Haila \& Margules 1996).

The importance of stands with high volumes of larger, well-decayed deadwood was evident. The sampling method precludes any inference about the role of deadwood in structuring beetle communities, as there is no evidence that beetles caught in traps also used deadwood as habitat. Evidence for a relationship between deadwood volume and beetle richness from other studies using the flight-intercept trap is mixed. Økland (1996) determined that to achieve a coefficient of determination $\left(R^{2}\right)$ above 0.1 between saproxylic beetle species richness and deadwood density required assimilating information over at least a 32 ha area. However, Sippola et al. (1992) did find a positive relationship between deadwood volume and richness of saproxylic beetles, using a sampling grain size of $1 \mathrm{ha}$. It is curious to note that in both hardwood and softwood stands, total species richness showed the same trend with deadwood volume. This may be due to increased deadwood-dependent fungal substrates, or because high deadwood is an indicator of high stand structural diversity. A number of studies have noted the importance of increased structural diversity to species diversity (e.g. Hansen et al. 1991, Freedman et al. 1994, Mason \& Quine 1995, Sippola et al. 1992), and attention to structural diversity is also a core concept of "new forestry" (Franklin 1989, Gillis 1990).

The influence of forest management on organisms has been described for a variety of taxa (see Heliovaara \& Vaisanen 1984, Freedman et al. 1994 for reviews). Of concern here is the decrease in deadwood in managed forests, relative to unmanaged forests (Hansen et al. 1991, Kirby et al. 1991), likely resulting from commercial thinning and short rotation ages. Several studies have reported a positive relationship between deadwood volume and stand age (Bormann \& Likens 1979, Bingham \& Sawyer 1988, Gore \& Patterson 1985, Kirby et al. 1991, Tyrell \& Crow 1994). In this study, we also saw an increase in deadwood volume with age in softwood stands, particularly large, well-decayed deadwood. The increase was linear across the range of ages sampled (40-140 years), suggesting that greater than 140 years is required for deadwood volume to stabilize following a disturbance. As the rotation age of most softwood forestry practices in Nova Scotia is considerably less than 140 years, and beetle richness increases with deadwood, there is potential for a strong negative impact of forestry on forest beetle species. In addition, any conversion of mixed-wood and hardwood forests to pure softwood stands will also diminish species richness in these stands, as hardwood stands showed a richer beetle community for almost all species groups. Forest managers also need to consider the implication of differing species composition between stand types for regional species diversity (Noss 1983).

Several authors have suggested that one way to simplify the arduous task of quantifying biodiversity is through the use of surrogate taxa, whose richness or abundance is correlated with the richness of other taxa (Brown 1991, Kremen 1992, Warren \& Key 1991, Oliver \& Beattie 1996b). Thus, ideally, biodiversity assessment and monitoring efforts need involve only a few species, reducing time and energy required. Forest stand variables are easier to quantify than species abundance, as they can be measured at the researcher's leisure, and require less expertise. We suggest that 
forest stand variables may prove more useful as indicators of beetle species richness, as has been clearly demonstrated for bird species richness (for brief review, see Noss 1983). The usefulness of this approach stems from the well known correlation between species diversity and habitat diversity (Murdoch et al. 1972).

Although deadwood represents an economic loss to the forest industry, deadwood also represents important habitat for beetles and other organisms. The difficulty lies in determining how much deadwood is required in forest ecosystems. Only more detailed information on the role of deadwood in structuring communities will resolve this challenge.

\section{Acknowledgments}

Field assistance was provided by L. Bishop, M. Hobbs, C. Underhill, K. Johnson. Specimens were identified with the help of K. Neil, J. MacPhee and the Canadian Agriculture and AgriFood Biosystematic Research Centre. We thank T. Duke, the NS DNR Wildlife Division and the NS DNR Pest Management Group for logistical support and helpful commentary. This research was supported by an NSERC PGS A fellowship to D. Kehler, an NSERC summer fellowship to C. Corkum, NSERC Operating Grant \# 0GP0046479 to S. Bondrup-Nielsen and funding from the Canada - Nova Scotia Cooperative Agreement for Forestry Development.

\section{References}

Adams EM, Morrison ML (1993) Effects of stand structure on red-breasted nuthatches and brown creepers. J Wildl Manag 57:616-629

Angelstam P, Mikusinski G (1994) Woodpecker assemblages in natural and managed boreal and hemiboreal forest - a review. Ann Zool Fenn 31:157-172

Araya K (1993) Relationship between decay types of deadwood and occurrence of Lucanid beetles (Coleoptera: Lucanidae). Appl Entomol Zool 28:27-33

Avery TE (1967) Forest measurements. McGraw-Hill Book Company, Toronto

Bader P, Jansson S, Jonsson BG (1995) Wood-inhabiting fungi and substratum decline in selectively logged boreal spruce forests. Biol Conserv 72:355-362

Baguette M, Gerard S (1993) Effects of spruce plantations on Carabid beetles in southern Belgium. Pedobiologia 37:129-140

Bakke A (1975) Aggregation pheromone in the bark beetle Ips duplicatus (Sahlberg). Norw J Entomol 22:67-69

Berg Å, Ehnström B, Gustafson L, HallingbäckT, Jonsell M, Weslien J (1994) Threatened plant, animal, and fungus species in Swedish forests: distribution and habitat associations. Conserv Biol 8:718-731

Bias MA, Gutierrez RJ (1992) Habitat associations of California spotted owls in the central Sierra Nevada. J WildI Manag 56:584-595

Bingham BB, Sawyer JO (1988) Volume and mass of decaying logs in an upland oldgrowth redwood forest. Can J For Res 18:1649-1651

Bondrup-Nielsen S (1996) (Centre for Wildlife Conservation Biology, Acadia University, Wolfville, NS). Unpublished report

Bormann FH, Likens GE (1979) Pattern and process in a forested ecosystem. SpringerVerlag, New York

Brown KS Jr (1991) Conservation of neotropical environments: insects as indicators. In: Collins NM, Thomas JA (eds) The conservation of insects and their habitats. Academic Press, London, p 350-401 
Buse A, Good JEG (1993) The effects of conifer forest design and management on abundance and diversity of rove beetles (Coleoptera: Staphylinidae): implications for conservation. Biol Conserv 64:67-75

Chandler DS, Peck SB (1992) Diversity and seasonality of Leiodid beetles (Coleoptera: Leiodidae) in an old-growth and a 40-year-old forest in New Hampshire. Environ Entomol 21:1283-1291

Conway CJ, Martin TE (1993) Habitat suitability for Williamson's sapsucker in mixedconifer forests. J Wildl Manag 57:322-328

Dillon ES, Dillon LS (1972) A manual of common beetles of eastern North America. Dover Publications, New York

Franklin JF (1989) Toward a new forestry. Am For (Nov-Dec):37-44

Franklin JF, Cromack K Jr, Denison W, McKee A, Maser C, Sedell J, Swanson F, Juday G (1981) Ecological characteristics of old-growth Douglas-fir forests. USDA Forest Service Gen Tech Rep PNW-118, Portland, OR

Freedman B, Woodley S, Loo J (1994) Forestry practices and biodiversity, with particular reference to the Maritime Provinces of eastern Canada. Environ Rev 2:33-77

Gillis AM (1990) The new forestry. Bioscience 40:558-562

Gore JA, Patterson WA III (1986) Mass of downed wood in northern hardwood forests in New Hampshire: potential effects of forest management. Can J For Res 16:335-339

Greenberg CH, Thomas MC (1995) Effects of forest management practices on terrestrial coleopteran assemblages in sand pine scrub. Fla Entomol 78:271-285

Hagan JM, Grove SL (1996) 1995 Report: Selection cutting, old-growth, birds and forest structure in Maine. Manomet Observatory Report MODCF-96002

Haila Y, Margules CR (1996) Survey research in conservation biology. Ecography 19:323-331

Halme E, Niemelä J (1993) Carabid beetles in fragments of coniferous forest. Ann Zool Fenn 30:17-30

Hansen AJ, Spies TA, Swanson FK, Ohmann JL (1991) Conserving biodiversity in managed forests. BioScience 41:382-392

Harmon ME, Hua C (1991) Coarse woody debris dynamics in two old-growth ecosystems. Bioscience 41:604-610

Harmon ME, Ferrell WK, Franklin JF (1990) Effects on carbon storage of conversion of old-growth forests to young forests. Science (Wash DC) 247:699-702

Harmon ME, Sexton J (1996) Draft guidelines for measurements of woody detritus dynamics. Department of Forest Science, Oregon State University, Corvallis, OR

Harmon ME, Franklin JF, Swanson FJ, Sollins P, Gregory SV, Lattin JD, Anderson NH, Cline SP, Aumen NG, Sedell JR, Lienkaemper GW, Cromack K Jr, Cummins KW (1986) Ecology of coarse woody debris in temperate ecosystems. Adv Ecol Res 15:133-302

Heliovaara K, Vaisanen R (1984) Effects of modern forestry on northwestern European forest invertebrates: a synthesis. Acta For Fenn 189:5-30

Ikeda K (1987) Distribution and habitat segregation of Japanese Platycerus species (Lucanidae). In: Kimoto S, Takeda H (eds) Insect communities in Japan. Tokai University Press, Tokyo, p 125-148

Kirby KJ, Webster SD, AntczakA (1991) Effects of forest management on stand structure and the quantity of fallen deadwood: some British and Polish examples. For Ecol Manag 43:167-174

Kremen C (1992) Assessing the indicator properties of species assemblages for natural areas monitoring. Ecol Appl 2:203-217 
Lindenmayer DB, Cunningham RB, Donnelly CF (1993) The conservation of arboreal marsupials in the montane ash forests of the central highlands of Victoria, southeast Australia, IV: The presence and abundance of arboreal marsupials in retained linear habitats (wildlife corridors) within logged forests. Biol Conserv 66:207-221

Loucks OL (1959) A forest classification for the Maritime Provinces. Proc NS Inst Sci 25:86-167

Marshall SA, Anderson RS, Roughley RE, Behan-PelletierV, Danks HV (1994)Terrestrial arthropod biodiversity: planning a study and recommended sampling techniques. A brief. Biological Survey of Canada (Terrestrial Arthropods)

Maser C (1994) Sustainable forestry: philosophy, science, and economics. St. Lucie Press, Delray Beach, FL

Mason WL, Quine CP (1995) Silvicultural possibilities for increasing structural diversity in British spruce forests: the case of Kielder Forest. For Ecol Manag 79:13-28

Mathsoft Inc (1995) S-Plus for Windows, Version 3.3, Release 1

Michaels KF, McQuillan PB (1995) Impact of commercial forest management on geophilous Carabid beetles (Coleoptera: Carabidae) in tall, wet Eucalyptus obliqua forest in southern Tasmania. Aust J Ecol 20:316-323

Murdoch WW, Evans FC, Peterson CH (1972) Diversity and pattern in plants and insects. Ecology (Tempe) 53:819-829

Niemelä J, Langor D, Spence JR (1993) Effects of clear-cut harvesting on boreal groundbeetle assemblages (Coleoptera: Carabidae). Conserv Biol 7:551-561

Niemelä J, Haila Y, Halme E, Lahti T, Pajunen T, Punttila P (1988) The distribution of Carabid beetles in fragments of old coniferous taiga and adjacent managed forest. Ann Zool Fenn 25:107-119

Noss RF (1983) A regional landscape approach to maintaining diversity. BioScience 33:700-706

Økland B (1996) A comparison of three methods of trapping saproxylic beetles. Eur J Entomol 93:195-209

Økland B, Bakke A, Hågvar S, Kvamme TF (1996) What factors influence the diversity of saproxylic beetles? A multiscaled study from a spruce forest in southern Norway. Biol Conserv 5:75-100

Oliver I, Beattie AJ (1996a) Designing a cost-effective invertebrate survey: a test of methods for rapid assessment of biodiversity. Ecol Appl 6:594-607

Oliver I, Beattie AJ (1996b) Invertebrate morphospecies as surrogates for species: a case study. Conserv Biol 10:99-109

Papp CS (1984) Introduction to North American beetles. Entomography Publications, Sacramento, CA

Pausas J, Braithwaithe LW, Austin MP (1995) Modeling habitat quality for arboreal marsupials in the South Coastal forests of New South Wales, Australia. For Ecol Manag 78:39-49

Siitonen J (1994) Occurrence of rare and threatened insects living on decaying Populus tremula: a comparison between Finnish and Russian Karelia. Scand J For Res 9:185-191

Sippola AL, Siitonen J, Jokimäki J, Inkeröinen J, Kallio R (1992) Effects of forest structure and vegetation on diversity of beetles (Coleoptera) and birds in north-boreal pine forests. In: Herman TB, Bondrup-Nielsen S, Willison JHM, Munro N (eds) Ecosystem monitoring and protected areas. Science and Management of Protected Areas Association, Wolfville, NS p 197-203 
Söderström L, Jonsson BG (1992) Fragmentation of old-growth forests and bryophytes on temporary substrates. Sven BotTidskr 86:185-198 (in Swedish with English summary)

Stewart GH, Burrows LE (1994) Coarse woody debris in old-growth temperate beech (Nothofagus) forests of New Zealand. Can J For Res 24:1989-1996

Stokland JN (1991) Skogbrukets innvirkning på truede og sårbara arter i barskog. Fauna (Oslo) 44:11-19

Stokland JN (1994) Biological diversity and conservation strategies in Scandinavian boreal forests. PhD thesis, University of Oslo

Stokland JN (1997) Representativeness and efficiency of bird and insect conservation in Norwegian boreal forest reserves. Conserv Biol 11:101-111

ter Braak CJF (1988) CANOCO Version 3.11. Agricultural Mathematics Group DLO, Wageningen, Netherlands

ter Braak CJF (1994) Canonical community ordination. Part I: Basic theory and linear methods. Ecoscience 1:127-140

Tyrell LE, Crow TR (1994) Structural characteristics of old-growth hemlock-hardwood forests in relation to age. Ecology (Tempe) 75:370-386

Warren MS, Key RS (1991) Woodlands: past, present and potential for insects. In: Collins NM, Thomas JA (eds) The conservation of insects and their habitats. Academic Press, London, p 155-203

Appendix 1 List of Families of beetle (order Coleoptera) with number of potential species caught during this study.

\begin{tabular}{lclc}
\hline Family & $\begin{array}{c}\text { \# of Potential } \\
\text { Species }\end{array}$ & Family & $\begin{array}{c}\text { \# of Potential } \\
\text { Species }\end{array}$ \\
\hline Alleculidae & 1 & Hydrophilidae & 1 \\
Anobiidae & 3 & Lampyridae & 2 \\
Buprestidae & 1 & Leiodidae & 3 \\
Byturidae & 1 & Leptodiridae & 1 \\
Cantharidae & 6 & Lucanidae & 2 \\
Carabidae & 5 & Lycidae & 3 \\
Cephaloidae & 1 & Lymexyloidea & 1 \\
Cerambycidae & 20 & Melandryidae & 7 \\
Cerylonidae & 2 & Melyridae & 1 \\
Chrysomelidae & 8 & Mordellidae & 2 \\
Ciidae & 1 & Nitidulidae & 12 \\
Cleridae & 3 & Oedomeridae & 1 \\
Coccinellidae & 5 & Pyrochroidae & 1 \\
Corylophidae & 1 & Pythidae & 1 \\
Cucujidae & 1 & Rhizophagidae & 1 \\
Curculionidae & 9 & Scarabaeidae & 8 \\
Dermestidae & 1 & Scirtidae & 3 \\
Dytiscidae & 1 & Scolytidae & 14 \\
Elateridae & 27 & Silphidae & 5 \\
Endomychidae & 1 & Staphylinidae & 21 \\
Eucnemidae & 1 & Tenebrionidae & 6 \\
Erotylidae & 2 & Tetratomidae & 1 \\
Histeridae & 1 & Throscidae & 1 \\
\hline
\end{tabular}


